\title{
A JURISTOCRACIA NO BRASIL E O FUTURO DA CONSTITUIÇÃO
}

\section{JURISTOCRACY IN BRAZIL AND THE FUTURE OF THE CONSTITUTION} JURISTOCRACIA EN BRASIL Y EL FUTURO DE LA CONSTITUCIÓN

\author{
Claudia MARIa Barbosa \\ https://orcid.org/0000-0002-7055-9403 / http://lattes.cnpq.br/0016091493799961 / claudia.mr.barbosa@gmail.com
}

Pontifícia Universidade Católica do Paraná, PUCPR. Curitiba, PR, Brasil

Universidade de Coimbra. CES Centro de Estudos Sociais. Coimbra, Portugal.

\begin{abstract}
RESUMO
Costuma-se associar de maneira virtuosa a expansão do Poder Judiciário, a constitucionalização de direitos e a efetividade do Estado Democrático de Direito, premissa contestada nesse artigo. 0 estudo bibliográfico qualitativo realizado analisa as características e a trajetória do constitucionalismo liberal, alguns traços de teorias constitucionais contemporâneas que explicam a expansão do papel do intérprete e da discricionariedade judicial, e a construção de Ran Hirschl sobre juristocracia, com o objetivo de sustentar a hipótese contrária: a de que o tipo de regime político da juristocracia que tem se fortalecido em democracias ocidentais é incompatível com o constitucionalismo liberal e fragiliza as Constituições desses Estados, tornando-as disfuncionais e incapazes de assegurar o equilíbrio de poderes, a defesa de direitos e conter o abuso do poder estatal. Inicia-se com uma abordagem teórico dedutiva com a qual explica-se cenários da juristocracia no estado democrático de Direito para, em seguida, analisar-se as especificidades da emergência da juristocracia no Brasil A conclusão é de que a juristocracia torna as constituições liberais disfuncionais e é um risco para o Estado Democrático de Direito no mundo e também no Brasil.
\end{abstract}

Palavras-chave: Brasil; constituição; estado democrático de direito; juristocracia.

\begin{abstract}
We commonly associate in a virtuous way the expansion of the judiciary, the constitutionalisation of rights and the effectiveness of the democratic rule of law, a premise that is contested in this article. The qualitative bibliographic study carried out analyzes the characteristics and trajectory of liberal constitutionalism, some features of contemporary constitutional theories that explain the expansion of the role of the interpreter and judicial discretion, and the construction of Ran Hirschl on juristocracy, in order to sustain an opposite hypothesis: that the type of political regime of the juristocracy that has been strengthened in western democracies is incompatible with the liberal constitutionalism and weakens their constitutions, making them dysfunctional and incapable of ensuring the balance of powers, the defense of rights and to contain the abuse of state power. The paper starts with a theoretical deductive approach used to analyze some scenarios of juristocracy, then followed by the the exam of some specificities of the emergence of juristocracy in Brazil. The conclusion is that juristocracy makes constitutions dysfunctional and represents a risk for the democratic rule of law in the word and also in Brazil.
\end{abstract}

Keywords: Brazil; constitution; democratic rule of law; juristocracy.

\section{RESUMEN}

Se suele asociar de manera virtuosa la expansión del Poder Judicial, la constitucionalización de derechos y la efectividad del Estado Democrático de Derecho, premisa contestada en este artículo. El estudio bibliográfico qualitativo realizado analiza las características y la trayectoria del constitucionalismo liberal, características de teorías constitucionales contemporáneas que explican la expansión del papel del intérprete y de la discrecionalidad judicial, y la construcción de Ran Hirschl sobre la juristocracia, con el objetivo de sostener la hipótesis contraria: la de que el tipo de régimen político de la juristocracia que se ha fortalecido en democracias occidentales es incompatible con el constitucionalismo liberal y fragiliza las Constituciones de esos Estados, haciéndolas 
disfuncionales e incapaces de asegurar el equilibrio de poderes, la defensa de derechos y contener el abuso del poder estatal. Se partió de un enfoque teórico deductivo con el que se explican escenarios de la juristocracia para luego analizar especificidades de la emergencia de la juristocracia en Brasil. La conclusión es que la juristocracia hace las constituciones disfuncionales y es un riesgo para el Estado Democrático de Derecho en el mundo y también en Brasil.

Palabras clave: Brasil; constitución; estado democrático de derecho; juristocracia.

\section{SUMÁRIO}

INTRODUÇAO; INTRODUÇÃO; 1 A TRAJETÓRIA DAS CONSTITUIÇÕES LIBERAIS; 2 A AMPLITUDE DA DISCRICIONARIEDADE JUDICIAL E DO PAPEL DO INTÉRPRETE NA TEORIA CONSTITUCIONAL CONTEMPORÂNEA; 3 O CONTEXTO DE AFIRMAÇÃO DA JURISTOCRACIA; 4 A DISFUNÇÃO DAS CONSTITUIÇÕES LIBERAIS NO AMBIENTE DA JURISTOCRACIA; 5 O CENÁRIO BRASILEIRO DE FRAGILIDADE CONSTITUCIONAL NA JURISTOCRACIA; CONCLUSÃO; REFERÊNCIAS.

\section{INTRODUÇÃO}

A associação positiva que usualmente é feita entre a constitucionalização de direitos, a expansão do Poder Judiciário e a realização do Estado Democrático é negada neste texto. Ela encontra obstáculos nos arranjos institucionais que hoje revelam a excessiva força do Poder Judiciário, em oposição à fragilidade da Constituição e, consequentemente, do poder constituinte que the deu origem. A hipótese explorada é outra: o tipo de regime político da juristocracia que tem se fortalecido em democracias ocidentais é incompatível com o constitucionalismo liberal e fragiliza as Constituições nesses Estados, tornando-as disfuncionais e incapazes de assegurar o equilíbrio de poderes, a defesa de direitos e conter o abuso do poder estatal.

Para a expansão do poder político dos magistrados em geral, e das cortes superiores em especial, concorrem as elites política, econômica e jurídica do país, as quais se articulam de modo a, no poder, defenderem os seus próprios interesses, favorecendo a juristocracia. 0 comportamento das elites favorece um governo de juízes, que se encarrega de proteger os interesses das elites política e econômica porque, como parte que são da elite, os juízes compartilham de seus mesmos interesses, assegurando o regime político que o cientista político canadense Ran Hirschl ${ }^{1}$ denominou juristocracia.

A investigação desenvolve-se no contexto do constitucionalismo liberal e da construção teórica apresentada pelo cientista político canadense Ran Hirschl do que ele considera a new

\footnotetext{
${ }^{1}$ HIRSCHL, Ran. Juristocracy - political, not juridical. The good society, v. 13, n. 3, 2004a.
} 
ISSN 1981-3694

(DOI): $10.5902 / 1981369434100$

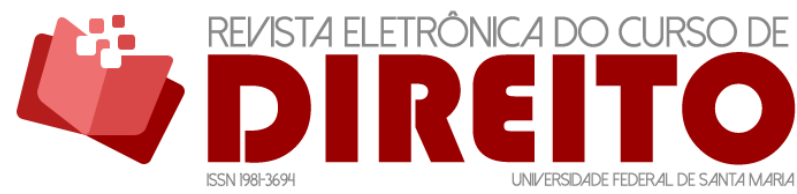

A JURISTOCRACIA NO BRASIL E O FUTURO DA CONSTITUIÇÃO

CLAUDIA MARIA BARBOSA

type of political regime ${ }^{2}$, denominado juristocracia. Na juristocracia a Constituição, os direitos ali protegidos e o próprio Estado Democrático são redefinidos no interesse das elites, pelo Judiciário, como se fossem “questões jurídicas", elidindo dessa forma o custo político de justificar propostas de governos que não se voltam à proteção dos interesses da maioria, servindo, antes, a uma minoria em seu próprio benefício. Para Hirschl, a atuação do Judiciário legitima governos elitistas. Assim, governos por vezes formalmente democráticos atuam contrariamente aos interesses da maioria, fragilizando as Constituições, na medida em que falham na sua função de proteger adequadamente e de forma isonômica os cidadãos e seus direitos, e mostram-se incapazes de garantir o equilíbrio entre os Poderes de Estado. Daí a pergunta que expressa o problema investigado: em um contexto em que se fortalece a Juristocracia, qual o futuro da Constituição?

O futuro das Constituições liberais pode ser analisado sob diferentes perspectivas, seja na esfera política, econômica, sociológica ou jurídica, e esse questionamento está diretamente relacionado ao futuro do próprio Estado $M_{0}$ derno $^{3}$, às potencialidades e desafios do chamado Estado pós-moderno ${ }^{4}$ e sua capacidade de fazer frente aos novos riscos de sociedades atuais. Sociedades ocidentais assentes sobre a matriz política e econômica do liberalismo já não cabem nos limites territoriais e não se limitam às fronteiras definidas no pós-guerra; a tecnologia e a própria globalização permitiu que grupos específicos identifiquem-se e unam-se às suas próprias "tribos" internacionais; ao invés de agruparem-se em seus próprios países, diferentes grupos e organizações confrontam cotidianamente o poder político centralizado, que não é capaz de lhes garantir segurança e promover dignidade. Neste cenário, soberania, território e poder político, os três elementos centrais do Estado Moderno, assumem novas perspectivas, que contrariam a ideia de Estado-Nação soberano típico da modernidade, o que pode impulsionar a emergência de novos paradigmas de organizações para as sociedades atuais.

Assim é que tanto a globalização quanto movimentos identitários ameaçam, cada um a seu modo, o modelo estatal e, por via de consequência, sua expressão jurídica máxima, as Constituições. Neste tabuleiro não se pode ignorar o papel das corporações que hoje têm mais poder do que grande parte dos Estados ditos nacionais ${ }^{5}$ e, ao contrário destes, que se justificam

\footnotetext{
2 HIRSCHL, Ran. Juristocracy - political, not juridical. The good society, v. 13, n. 3, 2004b, p. 7.

3 GIDENS, Anthony. A terceira via: reflexões sobre o impasse político atual e o futuro da socialdemocracia. Trad. Maria Luiza X. de A. Borges. Rio de Janeiro e São Paulo: Record, 1999.

${ }^{4}$ LYOTARD, Jean François. A Condição Pós-moderna. 12 ed. Rio de Janeiro: Editora José Olympio, 1979.

${ }^{5}$ GALINDO, Cristina. Quando as empresas são mais poderosas que os estados. El País - Brasil, $8 \mathrm{n} .2017$. Disponível em: https://brasil.elpais.com/brasil/2017/11/03/economia/1509714366_037336.html. Acesso em: 12 abr. 2018.
} 
ISSN 1981-3694

(DOI): $10.5902 / 1981369434100$

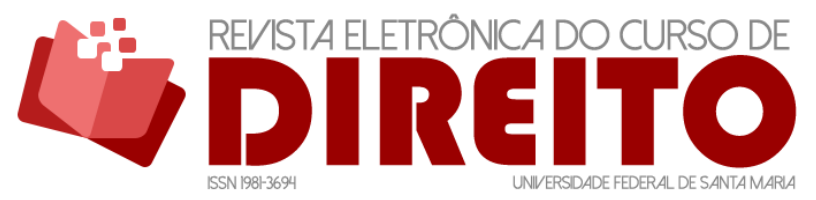

A JURISTOCRACIA NO BRASIL E O FUTURO DA CONSTITUIÇÃO

CLAUDIA MARIA BARBOSA

na busca do bem comum, encontram seu fundamento principalmente na defesa do interesse privado de seus acionistas "sem pátria e sem rosto", espalhados pelo mundo.

Para indagar sobre o futuro da Constituição, parte-se de um estudo bibliográfico qualitativo que apresenta as características e a trajetória do constitucionalismo liberal, traços de teorias constitucionais contemporâneas que explicam a expansão do papel do intérprete e da discricionariedade judicial, e a construção de Ran Hirschl sobre juristocracia. Analisa-se os limites das Constituições liberais sob a juristocracia e, em seguida, as especificidades com que ela vem se fortalecendo no Brasil. A conclusão é que a juristocracia fragiliza as Constituições, as torna disfuncionais e, desta maneira, ameaça o Estado Democrático de Direito no Brasil e no mundo.

\section{A TRAJETÓRIA DAS CONSTITUIÇÕES LIBERAIS}

Qual futuro existe para as Constituições liberais quando elas já não estão aptas a cumprir os papeis principais que justificaram sua força e existência? Constituições liberais são típicas do Estado Liberal que marcou o final do Século XVIII, com os processos da independência dos Estados Unidos da América e da Revolução Francesa. Esses documentos nascem e fundam-se na necessidade de limitar o poder do Estado, organizar sua estrutura e funcionamento, definir e proteger direitos fundamentais, precipuamente direitos de liberdade em sua dimensão individual. A proposta liberal política que acompanhou as constituições escritas encontrou eco no modo de produção que the é típico: o capitalismo.

A relativa estabilidade que o constitucionalismo liberal pode proporcionar no Século XIX começou a esvair-se com os processos revolucionários do início do Século XX, dos quais a Revolução Russa e a Mexicana foram seus exemplos mais notórios ${ }^{6}$.

Constituições como a alemã de Weimar, 1919, e a mexicana, 1917, refletiram exigências de movimentos revolucionários importantes, para estabelecer as bases de uma sociedade mais justa que valorizasse os trabalhadores e thes assegurasse melhores condições de vida. Inaugurando um primeiro momento do que alguns autores denominam constitucionalismo social, o qual, conforme aponta Rossi "se caracterizará, entre outros pontos, por acolher os direitos de segunda dimensão (sociais, econômicos e culturais) que se realizam por meio da

${ }^{6}$ ROSSI, Amélia do Carmo. Neoconstitucionalismo e a superação da perspectiva positivista do direito. 2011. 212 f. Tese. (Doutorado em Direito) - Universidade Federal do Paraná. Curitiba, out. 2011. p. 144 e ss. 
ISSN 1981-3694

(DOI): $10.5902 / 1981369434100$

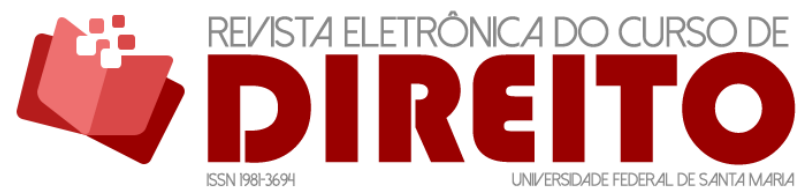

A JURISTOCRACIA NO BRASIL E O FUTURO DA CONSTITUIÇÃO

CLAUDIA MARIA BARBOSA

atuação estatal e que intentam a realização da igualdade material e da justiça social”7, essas Cartas, no entanto, foram enfraquecidas pela realidade do Pós-guerra e, depois, pela adoção de políticas keynesianas voltadas à constituição do que se considera o Estado Social ${ }^{8}$ que consolidou, especialmente na Europa, a chamada socialdemocracia.

As Cartas europeias que se sucederam à Il Guerra Mundial, como a Carta de Bonn alemã, em 1949, a Constituição da Quinta República francesa em 1958, a Constituição da Itália de 1947, Portugal, 1976, e Espanha, 1978, já no marco do que pode ser chamado de constitucionalismo contemporâneo 9 tiveram o seu escopo liberal ampliado. E, como um documento político então dotado de ampla normatividade, buscaram estabelecer novas bases da sociedade em que dialeticamente foram forjadas, em uma visão a um só tempo descritiva e prospectiva.

Essas Cartas mantiveram as funções clássicas das primeiras Constituições liberais, mas incorporaram direitos, especialmente os sociais, e realizaram um Estado de Bem-Estar Social que teve sucesso em assegurar aos europeus um período de paz, prosperidade e justiça social que perdurou até meados dos anos 70, quando fortaleceu-se o neoliberalismo. Este, conforme aponta Bedin ${ }^{10}$, encontrou em Hayek, Mises e Friedman, algumas de suas principais bases teóricas. Fundamentos neoliberais foram propulsionados de forma exitosa nos governos de Margareth Thatcher (1979), Ronald Reagan (1980) e Helmut Kohl (1982) e, na América Latina, Augusto Pinochet (1973), durante os quais encontraram suas mais fortes expressões políticas ${ }^{11}$.

$\mathrm{Na}$ esteira da redemocratização de Portugal e Espanha, no final dos anos 70, assim como na América Latina nas décadas de 80 e 90, as Constituições pós ditatoriais passaram a expressar preocupações sociais. A Constituição brasileira de 1988, a reforma de 1994 da Constituição argentina, a Carta colombiana de 1991, a Constituição peruana de 1993 incorporaram disposições nesse sentido ${ }^{12}$

No Brasil as dimensões coletivas de direitos individuais, os denominados novos direitos, alguns coletivos por natureza, passaram a ser constitucionalmente protegidos. Assim como o reconhecimento e proteção a grupos vulneráveis, ao meio-ambiente e aos usos de novas tecnologias, expandindo a intervenção do Estado em todos os domínios da vida em sociedade.

\footnotetext{
7 ROSSI, Amélia do Carmo. Neoconstitucionalismo e a superação da perspectiva positivista do direito. 2011. 212 f. Tese. (Doutorado em Direito) - Universidade Federal do Paraná. Curitiba, out. 2011. p. 151.

8 Ibidem, p. 153.

${ }^{9}$ Ibidem, p. 153 e ss.

${ }^{10}$ BEDIN, Gilmar Antonio. Os direitos do homem e o neoliberalismo. Ijuí: Editora Unijuí, 1997, p. 89 e ss.

11 Ibidem, p. 94 e ss.

12 PASTOR, Roberto, Viciano e DALMAU, Rubén Martinez. Los processos constituyentes y el nuevo paradigma constitucional. Revista del Instituto de Ciências Jurídicas de Puebla A.C., n. 25, 2010, p. 729.
} 
ISSN 1981-3694

(DOI): 10.5902/1981369434100

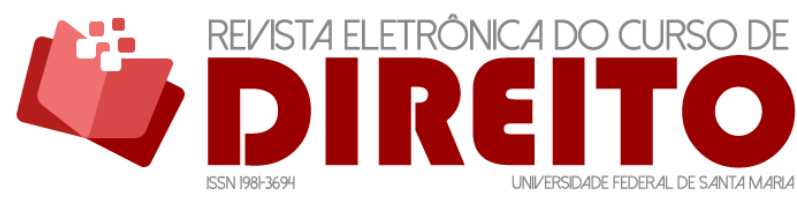

A JURISTOCRACIA NO BRASIL E O FUTURO DA CONSTITUIÇÃO

CLAUDIA MARIA BARBOSA

Estas Cartas constituem-se assim em novos marcos jurídicos das relações socioeconômicas no âmbito privado, público e nas interfaces entre ambos, marcadas pelo entendimento de que direitos sociais são essenciais à fruição da vida digna, em um contexto no qual a dignidade expressa um direito alçado à condição de fundamental.

Os modelos constitucionais forjados nos Século XVIII a XX, seja em países que se aproximaram do neoliberalismo ou do keynesianismo, são também liberais porque, essencialmente, mantém os elementos que the dão sustentação: governo limitado, direitos e garantias individuais protegidos, separação e harmonia dos Poderes para um funcionamento eficiente do Estado.

No Século XXI é possível enxergar o que para alguns autores como Wolkmer ${ }^{13}$ e Noguera Fernánde $z^{14}$ representa a emergência de um novo paradigma constitucional, em um conjunto de Constituições latino-americanas, especialmente as da Venezuela - 1999, Bolívia - 2009, e Equador - 2008 que, segundo eles, teria desafiado o desenho institucional clássico das Constituições liberais ${ }^{15}$. Outros autores, como Gargarella ${ }^{16}$, embora reconheçam especificidades nas experiências constitucionais latino-americanas, refutam a hipótese de que elas redesenharam o seu funcionamento, ou seja, não foram capazes de alterar a "sala de máquinas" e oscilam, portanto, entre o velho e o novo, sem constituir-se em novos paradigmas.

A dinamicidade com que o cenário latino-americano tem se alterado e a forte oposição aos novos desenhos que buscam afirmar o protagonismo do cidadão, ainda não permitem análises seguras sobre o potencial caráter inovador do constitucionalismo latino-americano. Mas é certo que as Constituições ousaram desafiar o caráter nacional do Estado moderno, reconhecendo Estados plurinacionais; criaram distintas instituições, como o poder cidadão na Venezuela e o participação cidadã e controle social no Equador, para assegurar o papel do cidadão no exercício do poder político; reconheceram novos direitos étnicos e linguísticos; propuseram novos arranjos institucionais que refutam a clássica separação de poderes de Montesquieu e o papel exclusivo do Judiciário na solução de conflitos.

\footnotetext{
${ }^{13}$ WOLKMER, Antônio Carlos. Pluralismo jurídico: fundamentos de uma nova cultura no direito. 4 ed. rev. atual. São Paulo: Saraiva, 2015.

${ }^{14}$ FERNÁNDEZ, Albert Noguera. What do you mean when we talk about 'critical constitutionalism'? Some reflection $s$ on the new latin American constitutions. In: NOLTE, Detlef e SCHILLING-VACAFLOR, Almut. New Constitutionalism in Latin America: promises and practices. Farnham, England e Burlington, USA, 2012, p. 99-122.

15 GARAVITO, César Rodrigues (coord.). El derecho en américa latina: um mapa para el pensamento jurídico del siglo XXI. 1 ed. Buenos Aires: Siglo Veinteuno Editores, 2011, p. 32 e ss.

${ }^{16}$ GARGARELLA, Roberto. La 'sala de máquinas' de las constituciones latinoamericanas: entre lo viejo y lo nuevo. Nova Sociedade, n. 258, jul-ago, 2015, p.96-106. Disponível em: http://nuso.org/media/articles/downloads/5.TC_Gargarella_258.pdf. Acesso em: 18 jun. 2018.
} 
ISSN 1981-3694

(DOI): 10.5902/1981369434100

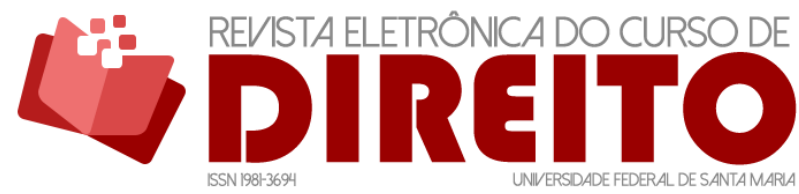

A JURISTOCRACIA NO BRASIL E O FUTURO DA CONSTITUIÇÃO

CLAUDIA MARIA BARBOSA

Assim, enquanto essas Constituições latino-americanas seriam capazes de propor novos modelos para exercício do poder político e a transformação do sistema político, as demais mantém as funções tradicionais próprias do Estado Liberal: organização do Estado, desenho de uma arquitetura institucional que assegure equilíbrio entre os Poderes e proteção dos cidadãos contra o abuso de autoridade, e reconhecimento e proteção efetiva de direitos. Essas são as funções que, conforme se busca demonstrar, estão ameaçadas atualmente, tornando possível temer-se pelo futuro das Constituições liberais.

\section{A AMPLITUDE DA DISCRICIONARIEDADE JUDICIAL E DO PAPEL DO INTÉRPRETE NA TEORIA CONSTITUCIONAL CONTEMPORÂNEA}

No contexto jurídico-político das Constituições liberais, a crítica ao positivismo jurídico operada desde a filosofia analítica ${ }^{17}$; a guinada epistemológica propiciada pela robustez do reconhecimento do Direito como linguagem, a partir do que foi possível, por meio do desvelar do que Warat ${ }^{18}$ chamou senso comum teórico dos juristas, desconstruir mitos do direito como neutralidade ou a segurança jurídica dos tipos penais; e as novas bases de teorias constitucionais que afirmam a indeterminação do conteúdo normativo de proposições constitucionais principiológicas, expuseram as limitações do positivismo jurídico e acabaram por subsidiar a ampliação do poder do intéprete para definir o alcance da norma e delimitar o escopo dos diretos fundamentais normativamente assegurados ${ }^{19}$.

Embora a interpretação se abra aos diversos atores sociais que atuam sobre a norma, aditindo-se, com Häberle ${ }^{20}$, ser este um grupo bastante plural, reconhece-se ao magistrado por meio da discricionariedade judicial, uma posição privilegiada no ato de interpreta-la e, assim, atuar como coconstituinte dos seus sentidos e alcance, um privilégio que desequilibra o arranjo clássico da tripartição do Poderes.

\footnotetext{
${ }^{17}$ NINO, Carlos Santiago. Introdução à análise do direito. São Paulo: Wmf Martins Fontes, 2010.

18 WARAT, Luis Alberto. Introdução geral ao direito. 1ed., vol. I, Porto Alegre, Sérgio Antônio Fabris Editor, 199, p. 13 e ss.

${ }^{19}$ STRECK, Lenio Luiz. Verdade e consenso: constituição, hermenêutica e teorias discursivas. 5 ed., rev., mod. e ampl. São Paulo, 2014, p. 68-83.

20 HÄBERLE, Peter. Hermenêutica constitucional: a sociedade aberta dos intérpretes da constituição: contribuição para a interpretação pluralista e 'procedimental' da constituição. 2 reimp. Trad. Gilmar Ferreira Mendes. Porto Alegre, Sérgio Antonio Fabris Editor, 2002.
} 
ISSN 1981-3694

(DOI): $10.5902 / 1981369434100$

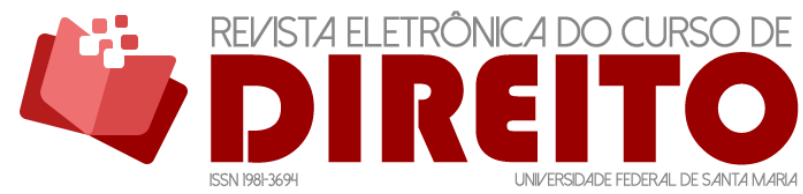

A JURISTOCRACIA NO BRASIL E O FUTURO DA CONSTITUIÇÃO

CLAUDIA MARIA BARBOSA

Verbicaro $^{21}$ relaciona quatro diferentes usos da discricionariedade judicial, entre os quais dois são de especial relevo à compreensão do papel decisivo do intéprete no processo de tomada de decisão operada no cenário da juristocracia. Verifica-se uma chamada discricionariedade fraca, "quando a decisão última sobre o justo no caso concreto é deferida à concepção individual da personalidade chamada a decidir”22. E uma discricionariedade forte, usada para designar "a possibilidade de eleição entre diferentes cursos de ação igualmente válidos e admissíveis, a que acena para a ausência de uma resposta jurídica unívoca”23.

Tanto na discricionariedade fraca quanto na forte, na medida em que se reconhece que o sentido da norma é atribuído pelo intérprete, esvazia-se o relevante papel do legislador porque a norma que ele promoveu e aprovou pode, pela via interpretativa, ter o seu conteúdo alterado, ficando cada vez mais difícil a distinção entre criar, interpretar e aplicar a norma, uma diferenciação importante na concepção tripartite do Poder. Daí porque, ainda que formalmente mantenha-se o mesmo desenho institucional de Montesquieu, a ampliação do espectro de atuação do Judiciário enfraquece a atuação do legislador, legitimada quase que exclusivamente em mecanismos periódicos de representação da vontade popular - o voto, que restringe a participação do cidadão ao momento da votação e dificulta o engajamento civil por meio do qual é possível atuar na formulação do conteúdo e do sentido das normas ${ }^{24}$.

Além do fortalecido papel do intérprete, a expansão da atividade do Judiciário revelase também no escopo das normas constitucionais que expressam direitos fundamentais. Questões sobre direitos fundamentais, quando judicializadas, são usualmente decididas por meio de técnicas que procuram assegurar a racionalidade e sobretudo a legitimidade do processo de tomada de decisão. 0 raciocínio preponderante, contudo, diferente do que propugnava o positivismo, já não é mais o subsuntivo, que pouco a pouco cede espaço à ponderação de princípios, onde o espaço da discricionariedade é muito maior, especialmente em um contexto de escassez de recursos no qual é comum ter-se que escolher um entre dois direitos fundamentais.

21 VERBICARO, Loiane Prado. A discricionariedade judicial e as condições de verdade das proposições jurídicas à luz do debate Hart e Dworkin. Revista do Curso da Direito da UFSM, v. 11, n. 2, p. 133-158.

22 Ibid., p. 138.

23 Ibid., p. 139.

24 BARBOSA, Claudia Maria. A legitimidade do exercício da jurisdição constitucional no contexto da judicialização da política. In: BARRETO, Vicente de Paulo, DUARTE, Francisco Carlos e SCHWARTZ, Germano. Direito da sociedade policontextural. Curitiba, Appris: 2013, p. 171-195. 
ISSN 1981-3694

(DOI): $10.5902 / 1981369434100$

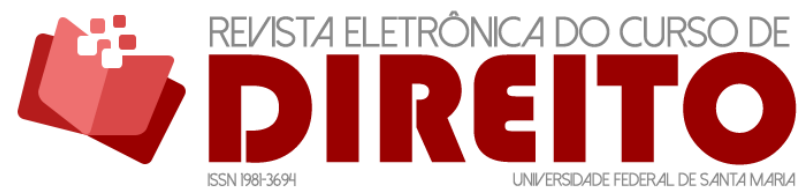

A JURISTOCRACIA NO BRASIL E O FUTURO DA CONSTITUIÇÃO

CLAUDIA MARIA BARBOSA

Barcelos $^{25}$ identifica na constitucionalização de direitos sociais uma terceira razão para a expansão da forte atuação dos magistrados. Para ela, a constitucionalização dos direitos sociais e a exigência por sua efetividade, aliada à tradicional incapacidade do Estado (liberal) de dar conta dos direitos assegurados, na amplitude com que foram garantidos, implicaram em um maior controle judicial sobre a atuação dos governos em torno da formulação, implantação e avaliação de políticas públicas. Neste caso o Judiciário amplia sua atuação tanto no âmbito material quanto no âmbito formal. No aspecto material ele passa a "corrigir políticas" ou "definir o conteúdo de tradicionais direitos de liberdade", ampliando o espaço do ativismo judicial. No formal, busca legitimar sua atuação como intérprete privilegiado (quando não último) da norma, ampliando seu papel enquanto ator político, sem a restrição que a responsabilidade política impõe aos atores políticos em regimes democráticos.

Os limites da discricionariedade judicial definem a compreensão do papel do intérprete, e essa era uma preocupação do positivismo jurídico que exponencialmente agiganta-se no contexto pós-positivista ${ }^{26}$, tornando-se uma questão central do debate entre substancialistas e procedimentalistas para a fundamentação da jurisdição constitucional ${ }^{27}$. Conforme registra Barbosa $^{28}$, enquanto Habermas, um expoente da corrente procedimentalista, confere as bases de uma democracia constitucional no processo de formação de vontades coletivas, forjada por pessoas que reconhecem-se como parte de uma comunidade de pessoas livres e iguais que, por isso, limitariam decisões que estivessem fora dos limites da moldura desenhada neste conjunto de valores, Dworkin, como representante do viés substancialista, refuta o caráter discricionário da atividade decisória, na medida em que reconhece a atividade interpretativa como a produção de um "romance em cadeia", legitimada pelo princípio da integridade.

Como se vê, a assunção do direito como linguagem, o escopo das normas definidoras de direitos e a amplitude do conteúdo das normas constitucionais, ampliam o papel do intérprete e aumentaram sua discricionariedade. O intérprete privilegiado da Constituição é o magistrado, e e de modo especial os juízes de cortes constitucionais, de maneira que esses elementos que envolvem a disputa sobre o conteúdo da Constituição e marcam o processo de tomada de

25 BARCELOS, Ana Paula de. Neoconstitucionalismo, Direitos fundamentais e controle das políticas públicas. Revista de Direito Administrativo, Rio de Janeiro, v. 240, p. 83-105, abr. 2005. ISSN 2238-5177. Disponível em: http://bibliotecadigital.fgv.br/ojs/index.php/rda/article/view/43620. Acesso em: 18 maio. 2018. doi:http://dx.doi.org/10.12660/rda.v240.2005.43620.

${ }^{26}$ ROSSI, op. cit., p. 20

27 BARBOZA, Estefânia Maria de Queiroz. Precedentes judiciais e segurança jurídica: fundamentos e possibilidades para a jurisdição constitucional brasileira. São Paulo: Saraiva, 2014.

${ }^{28}$ BARBOSA, Claudia Maria. op. cit., 2013, p. 09. 
ISSN 1981-3694

(DOI): $10.5902 / 1981369434100$

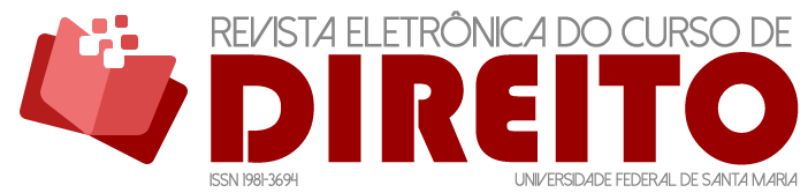

A JURISTOCRACIA NO BRASIL E O FUTURO DA CONSTITUIÇÃO

CLAUDIA MARIA BARBOSA

decisão, resultam no fortalecimento da atuação do Judiciário, ampliando em consequência os debates sobre como conter a discricionariedade judicial.

Todos esses fatores revelam o que Tate e Vallinder ${ }^{29}$ registraram em The Global Expansion of Judicial Power, título do trabalho publicado em 1994, no qual creditam o crescimento do Poder Judiciário ao fenômeno que intitulam judicialização da política.

Se a origem do termo parece recente, a preocupação com o chamado governo dos juízes, conforme relata Barbosa ${ }^{30}$, já havia sido muito bem pontuada na clássica obra 'The least dangerous branch', do norte-americano Alexander Bickel ${ }^{31}$, publicada em 1962. Nesta o jurista identifica no exercício do judicial review uma "dificuldade contramajoritária" do Judiciário para rever leis apoiadas pela maioria eleita. Ele, contudo, nega que isso represente um perigo porque entende, tal como expresso em The Federalist n. $78^{32}$, que “onde a vontade do legislador, declarada nas leis, colocar-se em oposição à vontade do povo, declarada na constitução, os juízes devem ser governados por estas e não por aquelas“33, afirmando então que o limite do judicial review está na vontade da Constituição, que não se confunde com a vontade dos juízes.

Sem refutar a judicialização da política, Ran Hirschl redimensiona a expansão global do Poder Judiciário em sua obra Towards Juristocracy: the origins and consequences of the new constitutionalism,34, na qual o autor chama a atenção para aquilo que considera "um novo método de concretização de objetivos políticos e gestão de assuntos públicos”35, por meio do ativismo.

${ }^{29}$ TATE, C. Neal e VALLINDER, Torbjörn. The global expansion of judicial power. New York e London: New York University Press, 1994.

${ }^{30}$ BARBOSA, 2013, op. cit., p. 13

${ }^{31}$ BICKEL, Alexander M. The least dangerous branch: the supreme court at the bar of politics. 2 ed. New Haven, USA e Londres, England: Yale University Press, 1986.

${ }^{31}$ HIRSCHL, 2004b, op. cit., p. 1.

32 HAMILTON, Alexander. The Federalist n. 78. Disponível em: https: / / www.congress.gov/resources/display/content/The+Federalist+Papers\#TheFederalistPapers-78. Acesso em: 08 jul.2018.

33 "(...) where the will of the legislature, declared in its statutes, stands in opposition to that of the people, declared in the Constitution, the judges ought to be governed by the later rather than the former". HAMILTON, Alexander. The Federalist n. 78. Disponível em: https://www.congress.gov/resources/display/content/The+Federalist+Papers\#TheFederalistPapers-78. Acesso em: 08 jul.2018.

34 HIRSCHL, Ran. Towards juristocracy: the origins and consequences of the new constitutionalism. Cambridge, Massachusetts and London, England: Harvard University Press, 2004b, p. 1.

35 “(...) a new method of poursing political goals and managing public affairs." 
ISSN 1981-3694

(DOI): 10.5902/1981369434100

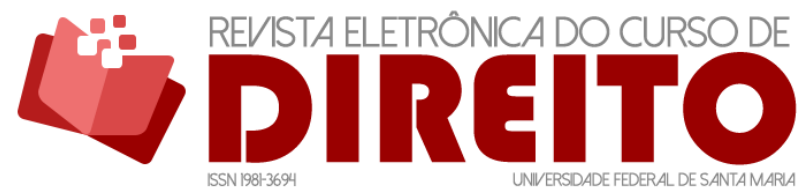

A JURISTOCRACIA NO BRASIL E O FUTURO DA CONSTITUIÇÃO

CLAUDIA MARIA BARBOSA

O cenário da expansão do Judiciário favorece o ativismo judicial que, por sua vez, aproxima o papel dos magistrados ao de "novos oráculos da lei”, expressão na qual Barbosa ${ }^{36}$ encontra eco para expressar o papel dos juízes na definição do significado da norma constitucional. Este cenário evidencia a interdependência entre o constitucionalismo, a constitucionalização de direitos, o ativismo judicial, a judicialização da política e o protagonismo político do Judiciário.

\section{O CONTEXTO DE AFIRMAÇÃO DA JURISTOCRACIA}

A Juristocracia afirma o protagonismo dos magistrados na interpretação e coconstituição do significado da norma, e reconhece um certo desequilíbrio no sistema de freios e contrapesos, mas repele o potencial conflito que existiria entre legislatura e Judiciário. Nega, portanto, existir eventual usurpação de poder operada pelo Judiciário em desfavor do Legislativo no processo de tomada de decisão.

O cientista político canadense Ran Hirschl ${ }^{37}$ explora seis cenários políticos em diferentes países com tradições jurídicas distintas, para concluir que a transferência de poder do Legislativo para o Judiciário se dá justamente quando as tradicionais elites se veem ameaçadas de perder poder porque passam a ser derrotadas nas urnas por candidaturas mais identificadas com a vontade e os interesses da maioria. Ou seja, quando candidaturas populares, usando das regras da democracia representativa que tradicionalmente beneficiou as elites, deixa de funcionar em proveito desses mesmos grupos.

$\mathrm{Na}$ análise dos cenários apresentados, Hirschl explica as origens do empoderamento judicial a partir de duas hipóteses centrais: ação estratégica e preservação hegemônica ${ }^{38}$. Para ele, a juristocracy consolida-se como consequência de uma forma autointeressada de preservação hegemônica, na qual as tradicionais elites estrategicamente cedem ao Judiciário parcela do poder político que antes detinham, porque se beneficiam desta transferência. Nesse sentido, a hipótese da juristocracia refuta tanto o caráter inexorável do processo de judicialização da política, quanto a ideia de que no cenário da judicialização o Judiciário estaria

\footnotetext{
36 BARBOSA, Claudia Maria. Os novos oráculos da lei: a experiência do modelo misto canadense e a proposta da súmula de efeito vinculante no Brasil. 2002. 226 f. Tese. (Doutorado em Direito) -Universidade Federal de Santa Catarina. Florianópolis, abr. 2002.

37 HIRSCHL, Ran. Towards juristocracy: the origins and consequences of the new constitutionalism. Cambridge, Massachusetts and London, England: Harvard University Press, 2004b, p 5-16.

38 Ibid., p 5-16; p. 38 e ss.
} 
ISSN 1981-3694

(DOI): $10.5902 / 1981369434100$

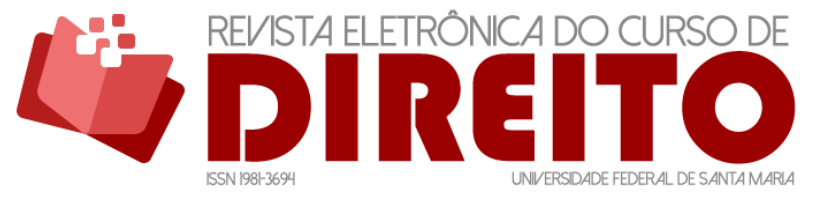

A JURISTOCRACIA NO BRASIL E O FUTURO DA CONSTITUIÇÃO

CLAUDIA MARIA BARBOSA

usurpando poder do Legislativo. Haveria, antes, um acordo entre as elites que, vendo enfraquecido seu poder nas urnas, decidem transferi-lo às cortes, sobretudo cortes constitucionais.

Hirschl explora quatro razões centrais para essa transferência. A primeira é a redução dos custos políticos na transferência ao Judiciário da tomada de decisões impopulares que desagradam partes sensíveis dos eleitores. A segunda remete ao apoio popular dado ao político por ele consentir em transferir decisões difíceis a um corpo profissional e aparentemente apolítico que possa toma-las de forma técnica e, portanto, mais segura. A a terceira quando grupos políticos defendendo posições divergentes não têm certeza do resultado e não querem arriscar suas preferência políticas em um debate em que podem ser derrotados, neste caso a transferência do poder decisório à Suprema Corte serve também para criar obstáculos àqueles que defendem interesses divergentes. E finalmente, a transferência de poder de decisão aos juízes acontece porque os detentores do poder político acreditam que suas preferências serão aprimoradas sob o regime político da juristocracia.

0 pesquisador canadense especifica duas diferentes estratégias de comportamento dos detentores do poder político em relação ao Judiciário: a fina - thin strategy, e a espessa - thick strategy $^{39}$. A primeira leva em conta sobretudo a lógica do mercado eleitoral, e considera que os detentores do poder político terão mais condições de negociar suas posições quando puderem oferecer aos grupos de interesse uma expectativa de que suas políticas serão permanentes e de longo prazo, de maneira a fortalecer parcerias duradouras. A segunda, espessa, é informada pela tese egoísta da preservação hegemônica, segundo a qual as elites política, econômica e jurídica agem por interesses diferentes, mas com o mesmo objetivo: preservar sua hegemonia e seus interesses. A elite política porque, ameaçada em sua hegemonia, busca preserva-la isolando o processo de elaboração de políticas das vicissitudes do jogo político. A elite econômica porque enxerga na constitucionalização de certas liberdades, especialmente as individuais, um caminho para promover a agenda neoliberal, os mercados abertos, a desregulação econômica e o antiestatismo, que seriam derrotados nas urnas. A elite judicial porque busca ampliar sua influência política e sua reputação internacional por meio de agendas que agradem ao status quo.

Em suma, as elites política e econômica, temerosas de perderem seus privilégios e serem derrotadas na esfera pública, agora tomadas por representantes mais próximos do Povo,

39 HIRSCHL, Ran. Towards juristocracy: the origins and consequences of the new constitutionalism. Cambridge, Massachusetts and London, England: Harvard University Press, 2004b. p 5-16, p. 42-49. 
ISSN 1981-3694

(DOI): $10.5902 / 1981369434100$

deliberadamente transferem parte do poder político que detém à elite jurídica que, ao final, como parte da mesma elite, é mais propensa a defender suas posições, preservando-lhes interesses comuns.

\section{A DISFUNÇÃO DAS CONSTITUIÇÕES LIBERAIS NO AMBIENTE DA JURISTOCRACIA}

Se a natureza das normas constitucionais e sua imperatividade ampliam a atuação do intérprete, então a delimitação dos direitos também depende dessa atuação. No modelo idealizado por Montesquieu de separação e harmonia entre os Poderes, o Legislativo detinha a legitimidade primária para definir o conteúdo da norma, e suas decisões eram submetidas à aprovação popular regularmente, de maneira que as eleições funcionavam com um mecanismo que $0^{\prime}$ Donnell ${ }^{40}$ denominou “accountability eleitoral vertical”, por meio da qual um mandato seria ou não renovado.

No constitucionalismo contemporâneo esse alinhamento, tão perfeito quanto o sistema de representação das candidaturas, se desfaz. Aos governantes continua cabendo a tarefa de legislar, mas a definição e a extensão do conteúdo dessas normas, especialmente quando relativas a direitos fundamentais (individuais, sociais, coletivos...) passa a ser crescentemente compartilhado com o intérprete privilegiado da mesma, os magistrados.

Entre o corpo de magistrados, os integrantes das cortes constitucionais têm um espaço ainda mais privilegiado que o dos juízes de primeiro grau, porque o escopo de intepretação normativa se amplia, de maneira que, na prática, transfere-se do Legislativo ao Judiciário questões tradicionalmente típicas do campo político, como são as questões relativas ao aborto, reconhecimento da união homoafetiva, descriminalização e liberação de drogas, extensão de direitos relativos à saúde, extensão de direitos reprodutivos, habitação, educação, etc.

Contudo, diferente dos mandatários eleitos, os membros do Judiciário, via de regra, não detém a legitimidade das urnas, e tampouco respondem politicamente ao eleitorado pelos seus atos, provocando uma disfunção no modelo tripartite de funcionamento do Poderes estatais, no qual a voz do Povo estaria representada no conteúdo das normas aprovadas pelo governo eleito. O deslocamento da definição do conteúdo do direito, do Legislativo ao Judiciário, enfraquece

40 O 'DONNELL, Guillermo. Accountability horizontal e novas poliarquias. Lua Nova, São Paulo, n. 44, p. 27-54, 1998. Disponível em: http://www.scielo.br/scielo.php?script=sci_arttext\&pid=S010264451998000200003\&lng=en\&nrm=iso. Acesso em: 24 jul. 2018. http://dx.doi.org/10.1590/S010264451998000200003. 
ISSN 1981-3694

(DOI): $10.5902 / 1981369434100$

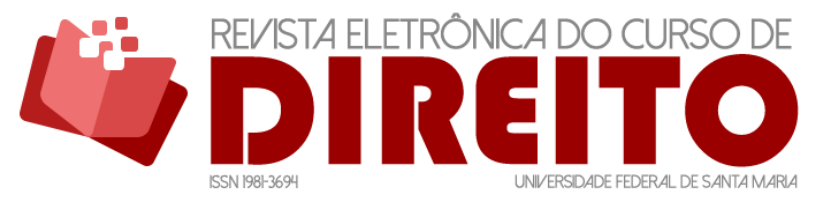

A JURISTOCRACIA NO BRASIL E O FUTURO DA CONSTITUIÇÃO

CLAUDIA MARIA BARBOSA

aquele e fragiliza o equilíbrio preconizado pelos checks and balances, comprometendo assim essa que é uma das funções clássicas das Constituições liberais, qual seja, o equilíbrio no exercício do poder.

Embora o escopo para definir o sentido e a extensão do conteúdo da norma tenha ampliado o papel do intérprete, o magistrado não sofre as mesmas restrições que possui o agente público político na gestão de políticas públicas, e tampouco está pressionado por interesses de seu eleitorado, de maneira que as condicionantes que levam o gestor governamental a realizar tal ou qual política, voltada ao interesse de um grupo maior ou menor da população, não são úteis para definir o comportamento do Poder Judiciário sobre políticas públicas.

Legisladores, gestores e juízes, mesmo quando agem em conformidade com a lei, o que supõe-se ser a regra, têm motivações diferentes na formulação e condução de políticas públicas. Políticos agem movidos por razões políticas e prestam contas diretamente ao cidadão que os elege, daí a razão de fundarem suas ações geralmente em benefício de uma maioria (ou de grupos que têm mais e melhores condições de ecoar ou sustentar sua vontade particular como se fosse da maioria). Magistrados, em contrapartida, não precisam atender aos anseios da maioria, sendo legítima a sua atuação contramajoritária, que ilustra a chamada dificuldade contramajoritária de que são revestidas algumas de suas decisões. A defesa judicial de direitos e interesses de grupos minoritários é um dos meios de que se valem estes grupos para verem assegurados direitos que, pela regra da maioria, teriam poucas chances de serem adequadamente protegidos.

No cenário descrito por Bickel a dificuldade contramajoritária expressa uma oposição entre a vontade da maioria, defendida pelo legislador, e o direito das chamadas minorias, grupos vulneráveis que não têm condições de pressionar o Legislativo para aprovar políticas e leis em seu favor, mas que têm sua condição de vulnerabilidade reconhecida pela Constituição, o que gera um dever de proteção pelo Poder Judiciário. 0 contraste entre a legislatura que atua majoritariamente, e o Judiciário, que tem legitimidade para atuar contramajoritariamente, fica fluído no regime da juristocracia, pois nele a defesa da Constituição é secundarizada, prevalecendo os interesses primários que aproximariam as decisões judiciais das posições expressas pelas elites política e econômica de um país.

Em suma, legisladores e juízes têm motivações e restrições distintas no que tange às políticas públicas, aos direitos que por meio dela se realizam e ao reconhecimento e garantia de direitos fundamentais, e não há razão específica para se acreditar que os juízes possuam uma 
ISSN 1981-3694

(DOI): $10.5902 / 1981369434100$

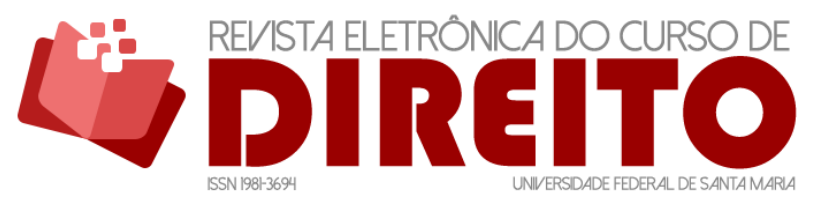

A JURISTOCRACIA NO BRASIL E O FUTURO DA CONSTITUIÇÃO

CLAUDIA MARIA BARBOSA

ética peculiar de correição diferente daquela dos agentes políticos ou dos atores privados. Ao contrário, o fato de os mecanismos de controle sobre a atuação do Judiciário serem muito frágeis, potencializa as possibilidades de abuso do poder.

É nesse mesmo sentido a advertência de Maus $^{41}$, para quem "quando a justiça ascende ela própria à condição de mais alta instância moral da sociedade, passa a escapar de qualquer mecanismos de controle social. Controle ao qual normalmente se deve subordinar todo (sic) instituição do Estado em uma forma de organização política democrática.

Nesse contexto, se se assume que os direitos constitucionalmente estabelecidos devem sua garantia à interpretação dos magistrados, confirmando a afirmação do ex-Presidente da Suprema Corte Norte-Americana Charles Hughes ${ }^{42}$, no sentido de que "estamos sob a égide de uma Constituição, mas a Constituição é o que os juízes dizem que ela é(...)"43, então as Constituições já não são capazes de proteger adequadamente os cidadãos, falhando em sua primária função de proteção dos direitos e garantias individuais.

Magistrados só defenderão os direitos dos cidadãos se, e na forma que, entenderem conveniente, e nesse sentido as Constituições tornam-se disfuncionais para outra finalidade essencial típica das Constituições liberais: a proteção dos direitos do cidadão contra o abuso de poder. $\mathrm{O}$ fato de o abuso eventualmente decorrer do Judiciário, e não dos governos, como ainda é mais comum, torna apenas mais evidente a disfunção.

Finalmente, se a tese da preservação hegemônica está correta, hipótese explorada nesse estudo, então legisladores e juízes colocam-se lado a lado para proteger uma concepção específica de bens e direitos, uma moralidade privada forjada por seus "modos de vida", próprios e comuns à elite, que via de regra não são compartilhados pelo conjunto da sociedade. Nesse desenho, o Judiciário já não serviria de freio ao Legislativo ou ao Executivo, e tampouco impulsionaria a efetividade de direito aos cidadãos, de forma que as Constituições liberais estariam falhando em sua terceira primordial função.

A exploração do espaço de contenção da discricionariedade judicial também não é promissora para o fortalecimento das Constituições. No cenário da juristocracia, o Judiciário distanciar-se-ia da ética Dworkiana de tratar a todos com igual respeito e consideração como forma eficaz de assegurar a liberdade preconizada pelos liberais. Também não encontraria freios

\footnotetext{
${ }^{41}$ MAUS, Ingborg. Judiciário como superego da sociedade - sobre o papel da atividade jurisprudencial na 'sociedade orfã'. Trad. Martônio Mont'Alverne Barreto Lima e Paulo Antonio de Menezes Albuquerque. Novos Estudos CEBRAP (impresso). São Paulo, v. 58, p. 183-202, 2000.

42 HUGUES, Charles Evan. Adresses and Papers of Charles Evan Hugues: governor of New York, 19061908. Nova York e Londres, The Knickerbocher Press, 1908, p. 139.

43 "We are under a Constitution, but the Constitution is what the judges say it is(...)"
} 
ISSN 1981-3694

(DOI): $10.5902 / 1981369434100$

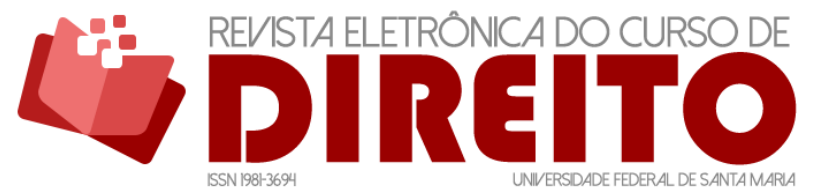

A JURISTOCRACIA NO BRASIL E O FUTURO DA CONSTITUIÇÃO

CLAUDIA MARIA BARBOSA

na ação discursiva de Habermas que fundamentaria sua ação, atuando de maneira perigosamente arbitrária.

Em suma, o protagonismo judicial torna as Constituições liberais disfuncionais, mas há outras consequências. Na transferência de poder do Legislativo ao Judiciário, este acaba por funcionar como um amortecedor político, transformando uma questão política sobre a qual a sociedade se divide (união homoafetiva, aborto, eutanásia, liberdade de expressão, etc.). Em uma questão aparentemente técnica, resolvida pela “correta” interpretação da norma, especialmente da norma constitucional. Com isso, neutraliza o conflito político, despolitiza e desmobiliza a sociedade, o que contribui também para que as elites se mantenham no poder, corroborando mais uma vez a hipótese de Hirschl de que a juristocracia beneficia as elites.

Ainda, o protagonismo político do Judiciário no cenário de judicialização da política fragiliza a Constituição porque desequilibra os Poderes republicanos, e o faz em favor justamente do Poder que é menos sensível, mais distante e menos accountable à sociedade, o próprio Judiciário. 0 fato de inexistirem mecanismos eficazes de controle institucionais ou sociais sobre a atuação do Judiciário, especialmente sobre membros das Cortes Superiores, nega a própria essência da República, qual seja, a possibilidade de responsabilização pelo exercício abusivo do Poder.

Por fim, o empoderamento judicial, especialmente dos membros da Suprema Corte, compromete o equilíbrio arquitetado por um sistema de freios e contrapesos, expõe arranjos pouco republicanos e relações possivelmente promíscuas entre governo (Legislativo e Executivo) e Judiciário, para a defesa de certos bens e direitos. Também nesse caso a Constituição, sob o domínio da juristocracia, deixou de ser eficaz na função de organizar o Poder do Estado e assegurar que seu exercício seja legal. Nesse sentido, as Constituições acabam por tornarem-se inúteis na proposição, via poder constituinte, e garantia, via poderes constituídos, de arranjos institucionais que assegurem o funcionalmente equilibrado dos Poderes republicanos.

Do exposto, buscou-se evidenciar que, no cenário da juristocracia, as três funções tradicionais das Constituições liberais: arquitetura do Estado, equilíbrio entre os Poderes e limitação do abuso de Poder, e reconhecimento e proteção dos direitos fundamentais, estão ameaçadas. Argumentou-se também que o agigantamento do Poder Judiciário potencialmente enfraquece a própria sociedade, ameaça o governo republicano e esvazia o poder constituinte. É portanto, um risco para a sobrevivência das Constituições liberais e, por via de consequência, dos Estados liberais. 


\section{O CENÁRIO BRASILEIRO DE FRAGILIDADE CONSTITUCIONAL NA JURISTOCRACIA}

As clássicas funções das Constituições liberais acima expostas, embora ameaçadas pelo proeminência do Judiciário, ainda são presentes, mas se apresentam na contemporaneidade com novas faces.

De fato, a organização do Estado, estruturada na separação de Poderes (ou de funções) e em mecanismos de freios e contrapesos que equilibram o exercício dos poderes Legislativo, Executivo e Judiciário, tem revelado neste Século XXI um protagonismo político deste último, em desfavor dos demais. No aspecto do reconhecimento e proteção de direitos, também há mudanças significativas, seja na classe de direitos protegidos (direitos de segunda, depois terceira e hoje quarta dimensões), seja no seu alcance, deslocando-se do direito individual para o direito coletivo. No que diz respeito à função de conter o abuso de poder, a legitimidade e a accountabiity ultrapassam a mera legalidade que, antes, era alegadamente suficiente para justificar um ato. Além disso, há também uma trajetória imensa percorrida desde a teoria da irresponsabilidade do Estado às teorias que, hoje, eventualmente reconhecem até a culpa objetiva do risco, que acolhe a responsabilidade do Estado pelo ato lesivo, mesmo sem que tenha havido a culpa do agente ${ }^{44}$.

Além das dificuldades no cumprimento de suas funções clássicas, a incapacidade de as Constituições oferecerem respostas satisfatórias aos novos desafios que fundamentam sua importância nos Estado democráticos liberais, parece evidenciar-se no mundo todo, como se pode observar na crise dos refugiados, em diferentes crises políticas que provocam a erosão da democracia, no aumento incontrolado do extremismo, nos crescentes limites da democracia representativa em assegurar eleições limpas e seguras, na incapacidade regulatória do Estado, revelada por exemplo na insuficiência de controle estatal sobre ações de grandes corporações. Esses fatores colocam em cheque a capacidade de as Constituições liberais cumprirem seus novos papéis em democracias ocidentais, incluindo o Brasil, onde esse desafio tem ainda outras especificidades.

No Brasil, o contexto pós-ditadura influenciou a Constituição de 88 , reconhecida como Constituição cidadã, e the impôs, além das típicas funções das Cartas liberais, a missão de

44 FACHIN, Zulmar. Responsabilidade patrimonial do estado por ato jurisdicional. Rio de Janeiro: Renovar, 2001. 
ISSN 1981-3694

(DOI): $10.5902 / 1981369434100$

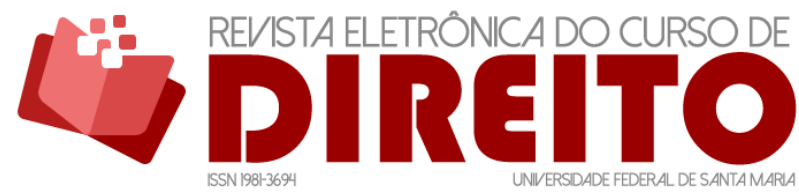

A JURISTOCRACIA NO BRASIL E O FUTURO DA CONSTITUIÇÃO

CLAUDIA MARIA BARBOSA

redemocratizar o país e construir uma sociedade mais livre, justa e solidária, conforme objetivos consagrados em seu Artigo 3‥ Nesse sentido, a previsão constitucional de uma amplo rol de direitos fundamentais consagrados (sociais, individuais, coletivos), e o reconhecimento de novos direitos e de novos atores jurídicos (coletividades e grupos vulneráveis, povos tradicionais, entre outros), expandiram a constitucionalização das relações sociais, entendida como a irradiação dos valores constitucionais pelo sistema jurídico ${ }^{45}$, e desenharam um constitucionalismo que acabou por exigir a ampliação de espaços decisórios, de forma a dar vazão às novas demandas que decorreram dessa constitucionalização.

A distância entre a previsão constitucional e a realidade social fez ampliar a atuação do Judiciário por meio de um comportamento ativista ${ }^{46}$, voltado às vezes a assegurar direitos que governo não podiam, ou não queriam, efetivar. 0 espaço do ativismo encontrou um ambiente favorável também no amplo exercício do controle de constitucionalidade, possibilitado pela inédita combinação tupiniquim de controle difuso e concentrado, para casos concretos ou leis em tese, a depender do caso. No Brasil a combinação de todos esses fatores favoreceu o protagonismo político do Judiciário e parece ter acentuado a percepção de que as Constituições são documentos apenas formais, cuja efetividade estaria além de suas disposições.

A constitucionalização das relações sociais colocou em evidência o sistema de justiça brasileiro e revelou no ativismo a possibilidade de efetivar direitos por vezes negado na burocracia dos gabinetes, ou mesmo na barganha política, ampliando assim as condições de legitimação social do Judiciário. Direitos sociais expandidos a uma parcela da população antes ignorada, aumentaram a expectativa da sociedade em relação à Constituição de 88 , na direção de um estado democrático de direito e de uma sociedade mais justa e solidária, de forma a atender aos ditames do já referido Artigo 3o, I, e assegurar os direitos do Artigo 5- da Carta brasileira.

Contudo, a crise política, acompanhada de uma retenção econômica que eclodiu após a vitória eleitoral da Presidente Dilma Roussef para o que seria o seu segundo mandato presidencial, interromperam esse processo. Aqueles que acreditaram na autocontenção do Judiciário para que a crise política ficasse restrita a essa esfera, deparam-se com um Poder que se acostumou ao protagonismo político e à visibilidade da mídia, e passou a interferir cada vez mais no processo político, a ponto de tornar-se seu principal ator, personificado no juiz que

\footnotetext{
45 BARROSO, Curso de direito constitucional contemporâneo: os conceitos fundamentais e a construção de um novo modelo. 2 ed. 2. Tir. São Paulo: Saraiva, 2011, p.58 e ss.

${ }^{46}$ KOERNER, Andrei. Jurisprudência constitucional e política no STF pós-88. In: Novos Estudos CEBRAP v. 96, jul. 2013, p. 69-85.
} 
ISSN 1981-3694

(DOI): $10.5902 / 1981369434100$

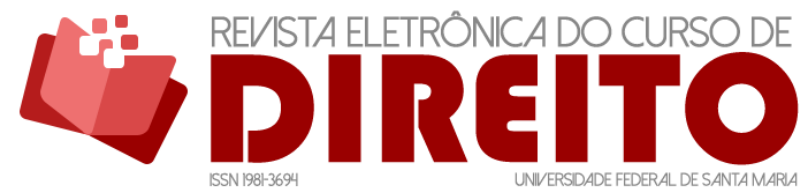

A JURISTOCRACIA NO BRASIL E O FUTURO DA CONSTITUIÇÃO

CLAUDIA MARIA BARBOSA

conduziu a operação Lava Jato ${ }^{47}$, mas estampado no rosto de cada juiz, desembargador ou ministro que afastou-se da necessária imparcialidade da Justiça e abraçou o holofote da politização da justiça.

No desenho institucional da Constituição de 88 , sua guarda e proteção caberiam precipuamente ao Supremo Tribunal Federal, mas esse desenho infelizmente virou rascunho. 0 ativismo em prol de direitos sociais que havia de certa forma marcado o comportamento do Judiciário no final da década de 90 e no início dos anos 2000, e que encontrava apoio no texto constitucional que determinava a construção de uma sociedade livre, justa e solidária, cedeu lugar a um comportamento punitivista de parcela do Judiciário, endossado pelo Supremo Tribunal Federal, que contraria a Constituição em seu viés garantista e protetivo dos direitos e garantias fundamentais ${ }^{48}$, permitindo até mesmo que decisões que ofendam o mais caro e elementar direito de liberdade, fosse baseada em falácias e mentiras ${ }^{4950}$.

O Judiciário hoje enfrenta o paradoxo de ser a um só tempo poderoso, pela força de suas decisões e fragilidade do controle que se possa exercer sobre ele; e fraco, porque deslegitimado perante a sociedade, conforme ilustrou pesquisa da Fundação Getúlio Vargas ${ }^{51}$. A politização da justiça revelou no país a sua face elitista e corroborou a hipótese da juristocracia.

O cenário em que Hirschl explica a tese da preservação hegemônica certamente vislumbrava um Corte Suprema guardiã de direitos e liberdades, em um cenário distante da corte penal punitivista que buscou legitimar o comportamento abusivo de ações da Operação Lava Jato. Infelizmente os pressupostos da hipótese da preservação hegemônica parecem adequar-se perfeitamente ao perfil da atuação institucional da Corte hoje.

\footnotetext{
47 Nome dado à operação judicial que investigaria casos de corrupção na Petrobrás, mas que acabou expandindo seu alcance e tornou-se a principal ferramenta para afastar da política, e das eleições o exPresidente Lula, candidato popular que tinha a preferência da maioria dos eleitores, mas não era bem quisto pelas elites.

48 BARBOSA, Claudia Maria. A crise do STF e a ameaça que vem de dentro. Gazeta do Povo, Curitiba, 09.jul. $2018 . \quad$ Disponível em https: / / www.gazetadopovo.com.br/busca/?q=claudia+maria+barbosa\&cx=014606829777116571431\%3A9ap b6tjyjba\&cof=FORID\%3A11. Acesso em: 12 jul. 2018.

49 BARBOSA, Claudia Maria. O lamento de aristóteles na decisão do caso "triplex de Lula": incorreições lógicas da sentença. In: PRONER, Carol; CITTADINO, Gisele et alli. Comentários a uma sentença anunciada - o processo Lula. Bauru: Canal 6 Editora, 2017, p. 110-122.

${ }^{50}$ MÜLLER, Luíz. Grande mídia apaga matérias e fotos que falavam do "luxuoso" triplex do Lula. Disponível em: https: / /luizmuller.com/2018/04/18/grande-midia-apaga-materias-e-fotos-que-falavam-do-luxuosotriplex-do-lula/. Acesso em: 18 jul. 2018.

${ }^{51}$ Fundação Getúlio Vargas. ICJ Brasil: Confiança da população nas instituições cai. Disponível em: https://portal.fgv.br/noticias/icjbrasil-2017-confianca-populacao-instituicoes-cai. Acesso em: 18 jul. 2018.
} 
ISSN 1981-3694

(DOI): $10.5902 / 1981369434100$

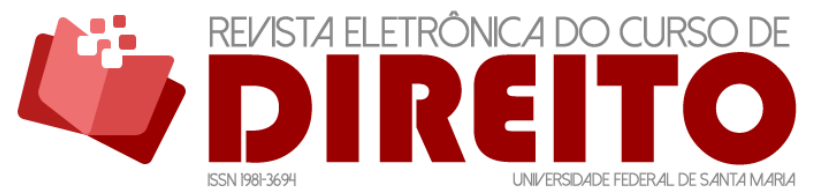

A JURISTOCRACIA NO BRASIL E O FUTURO DA CONSTITUIÇÃO

CLAUDIA MARIA BARBOSA

Assim é que, no cenário brasileiro, o futuro da Constituição liberal que é questionado no texto, já é uma interrogante no presente. O regime da juristocracia fragiliza a Constituição, torna-a inútil para a garantia da liberdade dos cidadãos, incapaz em conter os abusos de autoridade, frágil em assegurar o funcionamento harmônico, independente e responsável dos Poderes, e inepta no controle da atuação ilegal e abusiva dos agentes públicos.

\section{CONCLUSÃO}

O protagonismo político do Poder Judiciário em particular e das instituições do sistema de justiça em geral, conforme argumentou-se, provoca erosão no sistema de freios e contrapesos, do qual emergem diferentes arranjos institucionais que asseguraram a estrutura e funcionamento do Estado Liberal. Os arranjos liberais, ao longo dos Séculos XVIII, XIX, e XX, fizeram oscilar a hegemonia política, respectivamente entre os Poderes Legislativo, Executivo e, mais tardiamente, Judiciário, contrariando a lógica de Montesquieu, arquiteto do equilíbrio tripartite, que compreendia este último como um poder nulo, que apenas pronunciaria a vontade expressa na lei. Entretanto, o papel do Povo na condução dos negócios públicos não oscilou, seguiu uma lógica decrescente linear que diminui na proporção direta em que mina e coloca em risco a democracia liberal, cuja base é a representação.

0 afastamento do Povo no trato das questões políticas encontra alguma resistência nos processos constituintes latino-americanos, com a amplificação do Poder do cidadão no processo de debate e deliberação das novas Constituições, ainda na moldura da institucionalidade liberal.

De tempos em tempos, uma ruptura paradigmática ocorre e deste rompimento surgem formas diversas de organização da sociedade. É possível que se esteja vivendo a transição de um modelo hegemônico de organização social - estatal, para um outro modelo que ainda está sendo desenhado. Talvez essa transição ajude na compreensão da disfunção das Constituições liberais, explique o poder contemporâneo do Judiciário em democracias modernas, cujas esferas públicas estão fragilizadas, e permita vislumbrar cenários um pouco mais promissores à vida digna.

No momento, é certo que muitas Constituições atuais já não têm sido capazes de realizar as suas funções liberais clássicas ou contemporâneas. Ainda não está claro quais seriam seus novos papeis, ou se existe um, e qual sua importância em novos arranjos institucionais, que se estabeleçam ao lado de sua centralidade. De toda forma, conforme procurou-se mostrar nesse artigo, o cenário em que se formou e desenvolveu-se o Estado Democrático de Direito já não é 
ISSN 1981-3694

(DOI): $10.5902 / 1981369434100$

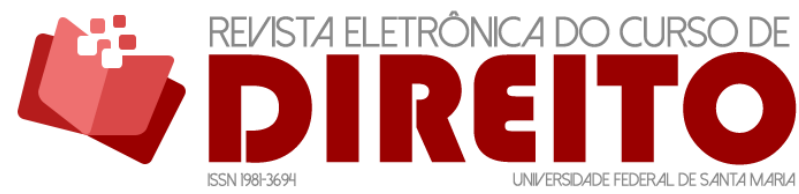

A JURISTOCRACIA NO BRASIL E O FUTURO DA CONSTITUIÇÃO

CLAUDIA MARIA BARBOSA

suficiente para justificar a essência ou o fundamento da Constituição. A amplitude do papel do intérprete e a discricionariedade judicial, mal delimitados no contexto da juristocracia, a enfraquecem.

No Brasil esse cenário é pior. A fusão operada entre a crise política que resultou no impeachment da Presidente Dilma Roussef, e a excessiva politização do sistema de justiça revelada na Operação Lava Jato, que levou ao abusivo e açodado julgamento e prisão o exPresidente Lula da Silva quando este encontrava-se em primeiro lugar nas pesquisas eleitorais, ampliou exponencialmente o papel político do Judiciário. A cumplicidade da mídia na cobertura da Operação Lava Jato, e a ausência de accountabiity judicial corroboram a hipótese de atuação das elites em favorecerem seus próprios interesses. Em ambos os casos, exarcebou-se a juristocracia teorizada por Hirschl.

A combinação de uma juristocracia forte e de uma Constituição incapaz de atender às funções que a legitimam, compromete o futuro das Constituições liberais e do Estado Democrático em democracias ocidentais, tais como o Brasil. 0 arranjo entre os tradicionais atores políticos, Judiciário inclusive, que opera o enfraquecimento da Carta brasileira, traz como consequência o afastamento do cidadão da Política, podendo provocar a erosão social, colocando em risco o Estado Democrático de Direito.

\section{REFERÊNCIAS}

BARCELOS, Ana Paula de. Neoconstitucionalismo, direitos fundamentais e controle das políticas públicas. Revista de Direito Administrativo, Rio de Janeiro, v. 240, p. 83-105, abr. 2005. ISSN 2238-5177. Disponível em:

http://bibliotecadigital.fgv.br/ojs/index.php/rda/article/view/43620. Acesso em: 18 maio 2018. doi:http://dx.doi.org/10.12660/rda.v240.2005.43620.

BARBOSA, Claudia Maria. A crise do STF e a ameaça que vem de dentro. Gazeta do Povo, Curitiba, 09.jul. 2018. Disponível em https: / / www.gazetadopovo.com.br/busca/?q=claudia+maria+barbosa\&cx $=0146068297771165714$ 31\%3A9apb6tjyjba\&cof=FORID\%3A11. Acesso em: 12 jul. 2018.

BARBOSA, Claudia Maria. O lamento de Aristóteles na decisão do caso "triplex de Lula": incorreções lógicas da sentença. In: PRONER, Carol; CITTADINO, Gisele et al. Comentários a uma sentença anunciada - o processo Lula. Bauru: Canal 6 Editora, 2017.

BARBOSA, Claudia Maria. A legitimidade do exercício da jurisdição constitucional no contexto da judicialização da política. In: BARRETO, Vicente de Paulo, DUARTE, Francisco Carlos e SCHWARTZ, Germano. Direito da sociedade policontextural. Curitiba: Appris, 2013, p. 171-195. 
BARBOSA, Claudia Maria. Os novos oráculos da lei: a experiência do modelo misto canadense e a proposta da súmula de efeito vinculante no Brasil. 2002. 226 f. Tese. (Doutorado em Direito) Universidade Federal de Santa Catarina. Florianópolis, abr. 2002.

BARBOZA, Estefânia Maria de Queiroz. Precedentes judiciais e segurança jurídica: fundamentos e possibilidades para a jurisdição constitucional brasileira. São Paulo: Saraiva, 2014.

BARROSO, Curso de direito constitucional contemporâneo: os conceitos fundamentais e a construção de um novo modelo. 2 ed. 2. tir. São Paulo: Saraiva, 2011.

BEDIN, Gilmar Antonio. Os direitos do homem e o neoliberalismo. Ijuí: Editora Unijuí, 1997.

BICKEL, Alexander M. The least dangerous branch: the supreme court at the bar of politics. 2 ed. New Haven, USA and London, England: Yale University Press, 1986.

FACHIN, Zulmar. Responsabilidade patrimonial do estado por ato jurisdicional. Rio de Janeiro: Renovar, 2001.

FERNÁNDEZ, Albert Noguera. What do you mean when we talk about 'critical constitutionalism'? Some reflection s on the new latin american constitutions. In: NOLTE, Detlef e SCHILLING-

VACAFLOR, Almut. New Constitutionalism in Latin America: promises and practices. Farnham, England and Burlington, USA, 2012, p. 99-122.

Fundação Getúlio Vargas. ICJ Brasil: Confiança da população nas instituições cai. Disponível em: https://portal.fgv.br/noticias/icjbrasil-2017-confianca-populacao-instituicoes-cai. Acesso em: 18 jul. 2018.

GALINDO, Cristina. Quando as empresas são mais poderosas que os estados. El País - Brasil, 8 n. 2017. Disponível em:

https://brasil.elpais.com/brasil/2017/11/03/economia/1509714366_037336.html. Acesso em: 12 abr. 2018.

GARGARELLA, Roberto. La 'sala de máquinas' de las constituciones latinoamericanas: entre lo viejo y lo nuevo. Nova Sociedade, n. 258, jul-ago, 2015, p.96-106. Disponível em:

http://nuso.org/media/articles/downloads/5.TC_Gargarella_258.pdf. Acesso em: 18 jun. 2018.

GARAVITO, César Rodrigues (coord.). El derecho en américa latina: um mapa para el pensamento jurídico del siglo XXI. 1 ed. Buenos Aires: Siglo Veinteuno Editores, 2011.

HÄBERLE, Peter. Hermenêutica constitucional: a sociedade aberta dos intérpretes da constituição: contribuição para a interpretação pluralista e 'procedimental' da constituição. 2 reimp. Trad. Gilmar Ferreira Mendes. Porto Alegre: Sérgio Antônio Fabris Editor, 2002.

HIRSCHL, Ran. Juristocracy - political, not juridical. The good society, v. 13, n. 3, 2004a.

HIRSCHL, Ran. Towards juristocracy: the origins and consequences of the new constitutionalism. Cambridge, Massachusetts and London, England: Harvard University Press, 2004b. 
ISSN 1981-3694

(DOI): $10.5902 / 1981369434100$

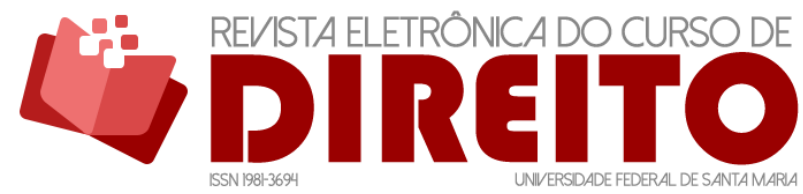

A JURISTOCRACIA NO BRASIL E O FUTURO DA CONSTITUIÇÃO

Claudia MARIA BARBosa

HUGUES, Charles Evan. Adresses and papers of Charles Evan Hugues: governor of New York, 1906-1908. Nova York and Londres: The Knickerbocher Press, 1908.

KOERNER, Andrei. Jurisprudência constitucional e política no STF pós-88. In: Novos Estudos CEBRAP (impresso) v. 96, jul. 2013, p. 69-85.

LYOTARD, Jean François. A Condição pós-moderna. 12 ed. Rio de Janeiro: Editora José Olympio, 1979.

MAUS, Ingborg. Judiciário como superego da sociedade - sobre o papel da atividade jurisprudencial na 'sociedade orfã'. Trad. Martônio Mont'Alverne Barreto Lima e Paulo Antonio de Menezes Albuquerque. Novos Estudos CEBRAP (impresso), São Paulo, v. 58, p. 183-202, 2000.

MÜLLER, Luíz. Grande mídia apaga matérias e fotos que falavam do "luxuoso" triplex do Lula. Disponível em: https://luizmuller.com/2018/04/18/grande-midia-apaga-materias-e-fotos-quefalavam-do-luxuoso-triplex-do-lula/. Acesso em 18.jul. 2018.

NINO, Carlos Santiago. Introdução à análise do direito. São Paulo: Wmf Martins Fontes, 2010. PASTOR, Roberto, Viciano e DALMAU, Rubén Martinez. Los processos constituyentes y el nuevo paradigma constitucional. Revista del Instituto de Ciências Jurídicas de Puebla A.C., n. 25, 2010, p. 7-29.

ROSSI, Amélia do Carmo. Neoconstitucionalismo e a superação da perspectiva positivista do direito. 2011. 212 f. Tese. (Doutorado em Direito) - Universidade Federal do Paraná. Curitiba, out. 2011.

TATE, C. Neal e VALLINDER, Torbjörn. The global expansion of judicial power. New York and London: New York University Press, 1994.

VERBICARO, Loiane Prado. A discricionariedade judicial e as condições de verdade das proposições jurídicas à luz do debate Hart e Dworkin. Revista Eletrônica do Curso de Direito da UFSM, v. 11, n. 2, p. 133-158.

WARAT, Luis Alberto. Introdução geral ao direito. 1ed. v. 1. Porto Alegre: Sérgio Antônio Fabris Editor, 1994.

WOLKMER, Antônio Carlos. Pluralismo jurídico: fundamentos de uma nova cultura no direito. 4 ed. rec. Atual. São Paulo: Saraiva, 2015.

STRECK, Lênio Luiz. Verdade e consenso: constituição, hermenêutica e teorias discursivas. 5 ed. ver. mod. e ampl. São Paulo: Saraiva, 2014. 
ISSN 1981-3694

(DOI): $10.5902 / 1981369434100$

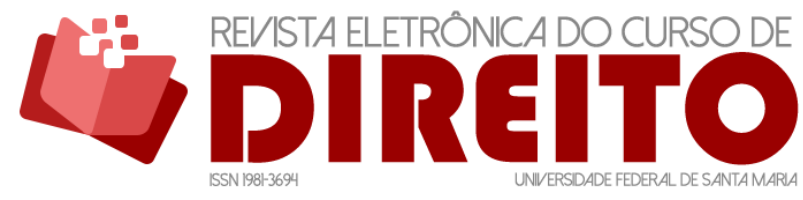

A JURISTOCRACIA NO BRASIL E O FUTURO DA CONSTITUIÇÃO

CLAUDIA MARIA BARBOSA

Recebido em: 02.08.2018 / Revisões requeridas em: 24.05.2019 / Aprovado em: 20.07.2019 / Publicado em: 14.08.2019

\section{COMO FAZER REFERÊNCIA AO ARTIGO (ABNT):}

BARBOSA, Claudia Maria. A juristocracia no Brasil e o futuro da Constituição. Revista Eletrônica do Curso de Direito da UFSM, Santa Maria, RS, v. 14, n. 2, e34100, maio./ago. 2019. ISSN 1981-3694. DOI:

http://dx.doi.org/10.5902/1981369434100. Disponível em:

https: //periodicos.ufsm.br/revistadireito/article/view/34100 Acesso em: dia mês. ano.

Direitos autorais 2019 Revista Eletrônica do Curso de Direito da UFSM

Editores responsáveis: Rafael Santos de Oliveira e Angela Araujo da Silveira Espindola

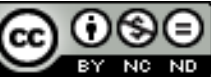

Esta obra está licenciada com uma Licença Creative Commons Atribuição-NãoComercial-SemDerivações 4.0

Internacional.

\section{SOBRE A AUTORA}

\section{CLAUdia MARIA BARBOSA}

Realiza Pós-doutorado na Universidade de Coimbra. Realizou Pós-Doutorado na York University, Toronto, Canadá. Fez graduação, mestrado e doutorado em Direito na Universidade Federal de Santa Catarina, com pesquisa em sistemas jurídicos comparados desenvolvida na Universidade de Montreal, CA. É professora titular da Pontifícia Universidade Católica do Paraná, onde dirigiu o curso de graduação e os programas de mestrado e doutorado em Direito. Suas linhas prioritárias de pesquisa são: política judiciária e administração da justiça; constitucionalismos e democracia; e organizações socioeconômicas e sociedades solidárias. Tem especial interesse em pesquisas interdiciplinares e estudos comparados. Leciona nos cursos de graduação, mestrado e doutorado em Direito da PUCPR, e é líder do grupo de pesquisa "Justiça, Democracia e Direitos Humanos". Integra o trustee committee da Law and Society. É também co-fundadora do Instituto Brasileiro de Administração do Sistema Judiciário-IBRAJUS e membro do Instituto Latinoamericano para una Sociedad y un Derecho Alternativos - ILSA, com sede na Colômbia; da Law and Society Association, USA; da International Sociological Association e da International Association for Philosophy of Law and Social Philosophy (Internationale Vereinigung für Rechts und Sozialphilosophie) - IVR. É parecerista de inúmeras revistas em sua área de pesquisa. Presta consultoria e assessoria técnica nas área de direito educacional, com especial ênfase na organização de mestrados e doutorados; direito e organizações do terceiro setor; direito digital; política judiciária e administração da justiça. 